\title{
Manufacturing, Manufacturing and Sports testimonials affecting Human Health
}

\author{
Aliyev Zakir Huseyn Oglu* \\ Professor, Institute of Erosion and Irrigation NAS of Azerbaijan, Azerbaijan
}

Received: January 17, 2018; Published: February 16, 2018

*Corresponding author: Aliyev Zakir Huseyn Oglu, Associate Professor, Institute of Erosion and Irrigation NAS of Azerbaijan, Azerbaijan, Tel: +994504242130; Email: zakirakademik@mail.ru

\section{Annotation}

In daily life, it is common to crush the various parts of the body. The crush is a result of a stroke caused by a stone, a bark, a wood, a piece of iron, and so on. Sometimes a person is crushed or smashed by a rigid body. Frustration often occurs at the head and in the upper part of the shaver.

Keywords: Capillary; Veins; Pulse; Trauma; Trachea; Groin; Tissues

\section{Fragile Tissues}

Bearing in mind that crushing does not break the integrity of the top sheets (upper layers) and is considered only as damage to the soft tissues inside the interior, it is not difficult to understand the horrors of its horizons. In the first sense, this can be summed up in a short scientifically-practical explanation. For example, when a perverse tool touches a certain part of the body, the tissues of this part of the body are rapidly collected and squeezed. In this case, the upper layers protect their integrity because of their elasticity, and subcutaneous tissues are crushed and broken. During the crush, the soft connective tissue rich in large veins (capillaries and veins) is faster and easier to break apart. Resistance to dense beams and nerve bumps increases. Tissue damage is consistently damaged, depending on their various resistance forces.

At first, the most delicate tissue injuries. Dense, coarse tissues are also damaged when impact or pressure persists or aggravates. However, this is essentially minor, minor failures. In the strongest crunch, ie the pressure displayed, the muscle, the muscles, the nerves, and the large veins break down when the impact is strong. In a cramped area, the soft connective tissue inflates, tears and tears, mixes with blood, where it is found in fragmented muscle fibers, separated fatty vessels, and others. When the toughness to the body is strong and the pressure is strong, the tissues are completely crushed and the blood is mixed with the tissues that are scratching, creating something like bloody horror.

\section{No fatigue}

According to doctors, the main symptom of the crush is the leakage of blood from broken veins to tissues. This type of hemorrhage can be very small or vice versa strong, and in some cases it also results in the accumulation of large amounts of blood.

Four types of obesity are distinguished:

1. The first exit point is clear and selective blood loss in small and inferior;

2. The second outlet, the surface and the breech;

3. The third, large-scale, large-scale hemorrhages. This type of hemorrhage is caused by damage to the vessels. Blood flows slowly to soft tissues and subcutaneous cells.

4. Fourth, hematomas or blood tumors. These are the result of accumulation of a large amount of blood. Blood pumps the tissues under high pressure and splits them into bloody hollows where they are cured by hematoma in medical science.

One of the main features of hematoma is its rapid formation. Hematoma is more pronounced in the head of the body. After a short break, jaundice traumatic inflammation begins and at the same time the veins are expanded, and multicellular leukocytes are replaced. As a result of the injury, the most affected tissues slowly become necrotic, die, and die. After a certain period of time, there is a dense connective tissue - an internal scar on the area of the erysipelas and dead tissues.

\section{Pain, Swelling, Bruise}

As it is known, one of the main signs of crushing is pain. The severity and properties of pain depend on the degree of damage and the depth of the pain, and are effective in different ways. It is caused by the pain of the nerves of the pain and its squeezing 
as a result of the sore throat, which is severe damage to the abdominal cavity, breast and other organs, as if it is shocking. One of the symptoms of diarrhea is "edema" (swelling). "Ödem" occurs as a result of the accumulation of blood and lymph nodes in the cavities and subcutaneous cells: "Bleeding occurs in the body along with edema after the crush, which results from hemorrhage, often seen 2-3 days after the bleeding, because the hemoglobin tissues and as a result, the tissues get a certain color. Fresh bruises are black, blue and gray, and sometimes in red, depending on the severity and power of the liver, in some cases, the function of this or another member may also be disrupted, for example, when the muscles their movements are violated, so certain member is deprived of his position and ability at a certain time."

\section{Danger of Decay}

In the opinion of traumatologists, tissue feeding is greatly damaged in large pests and they are perishable and necrotic. Such a necrosis may be limited in a certain place. However, as a result of injury, large or large areas are crushed, and separate parts of the body are completely necrotic. In such cases, the surroundings are yellowed and cooled, pulse, feelings, movement are gradually weakening, white rising, and finally necrosis begins to develop. The muscular R. Bagirov emphasized that the muscles were severely crushed as a result of impact, pus, fall, hard application.

When the crunch is light, only some muscle fibers are damaged and the muscle fits into the muscle. In severe cases, large muscle hematomas can develop. At the most severe injury, the muscle is completely crushed, resulting in muscle tissue that is often crushed under the skin. The main symptoms of muscle cramping are pain, swelling, tremor. This situation should last for several days. However, in severe cases of hematoma, the healing process and soreness are poor, slow, and there is a bump in the form of injury. When the muscle is completely crushed, the wound gradually heals along with the development of large scar on the wound: "Damaged muscle is treated with hot compresses, tight dressing and massage, and sometimes surgery." Damaged vessels According to physicians, tissues the blood flowing through the bloodstream causes inflammation. In many complications, these defects are self-absorbed and lost.
At the time of questioning, blood clots begin to develop in the outer part of the abdomen, and in the middle, the blood remains in liquid state. Thus, a sharp swelling occurs. Hematomas may be infected with exogenous or endogenous pathologies. A scar tissue is formed in the connective tissue scar in the muscle.

Hematoma, which is a pulse, often occurs in inflammation of large blood vessels, firearms and other open injuries. The injury time is sometimes caused by external bleeding, with the pressure in the artery removed from the blood-forming injury hole and enters the nearest tissue, absorbs and splits. The damaged hole in the blood vessel is usually left open. There is a constant relationship between the blood vessel and the empty space.

Treatment of Patients By the words of Prof. R. Bagirov, there are three basic means of treating criminals in Azerbaijan. These are direct, complicated and challenging means, and are used as slimming dressing, cooling, and other therapeutic treatments. An aggressive bandage stops bleeding and spreads leaking blood to the wide area as possible, making it easier to ask for it. After crushing, use colds (ice, cold compress, etc.) to stop bleeding. As a result of the effects of the colds, the veins are tightened, the nerves' sensitivity and pain are reduced. When surroundings are damaged, you need to raise them slightly. The upside-down triangle is mounted on a rug with a low, slightly above the raised pillow. As a result, the flow of blood and lymph can be facilitated, and favorable conditions for hemorrhoids are: "Heat and massage, as heat treatment compresses, especially domestic light baths, hot air, and hot water filled glass, rubber balloon or simply heated Massage is the most effective means to enhance the absorption of blood, lymph and inflammatory exudates.

The importance of the massage during crush is to spread the inflammation of the tissues and the blood, thus enhancing the absorption and leading the pathological mass to the lymph nodes. As for fighting, it is the treatment of hematoma, which is the primary cause of hematoma. Massage is used. A bruised as a result of complications with pus-pus torəndikdə open source and there is a long incision and drainage should be put."

\section{Your next submission with Juniper Publishers will reach you the below assets}

- Quality Editorial service

- Swift Peer Review

- Reprints availability

- E-prints Service

- Manuscript Podcast for convenient understanding

- Global attainment for your research

- Manuscript accessibility in different formats

( Pdf, E-pub, Full Text, Audio)

- Unceasing customer service

Track the below URL for one-step submission https://juniperpublishers.com/online-submission.php 